\title{
Intensification of bituminous coal and lignite oxidation by copper- based activating additives
}

\author{
K.B. Larionov ${ }^{1}$ (I) I.V. Mishakov ${ }^{2} \cdot$ K.V. Slyusarskiy ${ }^{1}$ A.A. Vedyagin ${ }^{1,2}$
}

Received: 23 October 2019/Revised: 20 May 2020/ Accepted: 8 July 2020/Published online: 23 July 2020

(C) The Author(s) 2020

\begin{abstract}
The oxidation of lignite and bituminous coal samples modified by $5 \mathrm{wt} \%$ (in terms of dry salt) addition of copper salts $\mathrm{Cu}\left(\mathrm{NO}_{3}\right)_{2}, \mathrm{CuSO}_{4}$, and $\mathrm{Cu}\left(\mathrm{CH}_{3} \mathrm{COO}\right)_{2}$ was studied. The samples' reactivity was studied by thermogravimetry within a temperature range of $45-600{ }^{\circ} \mathrm{C}$ at a heating rate of $2.5^{\circ} \mathrm{C} / \mathrm{min}$ in an oxidizing environment. The introduction of activating additives has resulted in a significant decrease in the temperature of intense oxidation onset $\left(\Delta T_{\mathrm{i}}=20 / 94{ }^{\circ} \mathrm{C}\right)$, in a reduction in the sample residence time in the volatile matter release region $\left(\Delta t_{\mathrm{e}}=2 / 22 \mathrm{~min}\right)$ and the total duration of the coal combustible mass oxidation $\left(\Delta t_{\mathrm{f}}=8 / 14 \mathrm{~min}\right)$. The Friedman method was used to calculate the activation energy values for the oxidation process of the modified samples. The maximum change in activation energy values was observed for the bituminous coal sample. The possible mechanism behind the action of the copper-salt additives, which activate the oxidation of lignite and bituminous coal, is discussed. According to the data of mass spectrometric analysis, the concentration of $\mathrm{NO}_{x}$ in the reaction products decreases as the temperature of the activated oxidation process is shifted towards the low-temperature region.
\end{abstract}

Keywords Coal $\cdot$ Activated oxidation $\cdot$ Copper nitrate $\cdot$ Copper sulfate $\cdot$ Copper acetate $\cdot$ Thermo-gravimetric and mass spectrometry analysis

\section{Introduction}

With the continuous growth of coal consumption for the needs of the power industry (IEA 2017), there is an actual challenge to improve technological approaches for designing new and modernizing existing fuel-burning equipment. One of the promising ways to enhance the efficiency of the apparatus related to coal energy is the catalytic combustion of solid fuels (Parmon et al. 2015). This method is based on the effective initiation and intensification of the combustion process of coal as a result

K.B. Larionov

laryk070@gmail.com

1 National Research Tomsk Polytechnic University, Tomsk, Russia 634050

2 Boreskov Institute of Catalysis SB RAS, Novosibirsk, Russia 630090 of activation of the oxidizing agent (in most cases-oxygen (Simonov et al. 2013), which is accompanied by a significant decrease in the temperatures of the oxidation reactions (by $350-750{ }^{\circ} \mathrm{C}$, depending on the coal type). If compared with traditional ways to burn the coal, the catalytic approach makes it possible to soften the requirements for the thermochemical characteristics of the equipment construction materials, reduce the heat losses, simplify the process control and eliminate the undesirable endothermic processes, which often lead to the formation of secondary pollutants (Ismagilov and Kerzhentsev 1999).

Most of the researches in the field of catalytic combustion of coal are focused on the use of various metal oxides (Gong et al. 2009, 2010a, b; Wei et al. 2012; Huang et al. 2013; Zhao et al. 2011). Thus, as reported by Guo et al. (2014), the simultaneous introduction of $\mathrm{Fe}_{2} \mathrm{O}_{3}$ and $\mathrm{K}_{2} \mathrm{CO}_{3}$ affects the kinetic characteristics of the combustion of coals with different ranks. 
The results of the thermal analysis revealed that the introduction of additives resulted in a decrease in the initial ignition temperature and an acceleration of the thermal decomposition and combustion of various solid fuels. It was found that the character of the influence of the activating additives upon the combustion characteristics depends strongly on the carbon content in the composition of original coal and has a tendency to be increased with increasing the coal porosity.

An important factor affecting the change in the coal ignition temperature is the volatile matter pyrolysis rate (Wang et al. 2012). According to the multiple studies (Morgan and Jenkins 1986a, b; Jenkins and Morgan 1986), metal cations contained in the high molecular weight structure of coal contribute to decelerating the volatile matter release. Thus, the higher the yield of volatile substances, the lower the catalytic effect of the additives used. At the same time, the change in the initial ignition temperature of fuels of different ranks is explained by the nature of the oxidation reaction (homogeneous or heterogeneous) (Gong et al. 2010a).

It was suggested by Guo et al. 2014 that metal oxides can be reduced to a metallic state or oxides with a lower valence as a result of the interaction with carbon; after the contact with oxygen, they may return to their initial state. Thus, this process consists of repetitive cycles of subsequent oxidation and reduction stages. The transfer of active oxygen from metal to carbon substrate accelerates the oxidation process of the released pyrolysis gas ( $\mathrm{Li}$ et al. 2007), followed by the combustion of the coke-forming residue.

Moreover, in numerous papers, it is mentioned that the solid oxide precursors (salts and their bases) are characterized by strong oxidizing properties, low melting (decomposition) temperatures, and good solubility in water (Morozov et al. 2003; Ryu et al. 2004). The latter simplifies their introduction significantly by means of impregnation of the solid fuels.

For example, the introduction of $\mathrm{Ni}\left(\mathrm{NO}_{3}\right)_{2}$ as an activating additive was found to cause the maximum decrease in the ignition temperature of lignite (by about $50{ }^{\circ} \mathrm{C}$ ) if compared with the addition of the following metal oxides: $\mathrm{CaO}, \mathrm{Al}_{2} \mathrm{O}_{3}, \mathrm{Fe}_{2} \mathrm{O}_{3}$ and $\mathrm{CeO}_{2}$ (Gong et al. 2010a; Zhao et al. 2011). It should be noted that the nitrates decompose with the formation of the corresponding transition metal oxides, which are known to be capable of catalyzing further coal oxidation (Ryu et al. 2004).

On the other hand, it was also reported that the use of $\mathrm{CuO}$ as an activating additive resulted in a significant increase in the reaction rate $\left(\Delta w_{\max }=+4 \% / \mathrm{min}\right)$ with the corresponding drop of the burning temperature of volatile matter and coke residue $\left(\Delta T=50{ }^{\circ} \mathrm{C}\right)(\mathrm{Li}$ et al. 2007). Up to now, salts-precursors of $\mathrm{CuO}$ were not yet studied. As was recently found in our previous research, the addition of copper nitrate had very positive effect on oxidation kinetics of lignites, as compared with other metal nitrites studied as activating additives (Larionov and Gromov 2019). So, in the current paper we tried to study the extended set of different copper salt precursors- $\mathrm{Cu}\left(\mathrm{NO}_{3}\right)_{2}, \mathrm{CuSO}_{4}$ and $\mathrm{Cu}\left(\mathrm{CH}_{3} \mathrm{COO}\right)_{2}$ - which could promote the oxidation of coals with different level of coalification.

\section{Experimental}

\subsection{Preparation of coal samples and their characterization}

The following coal samples were studied: lignite of the Borodinsky opencast mine of the Kansko-Achinsk coal basin (sample L) and bituminous coal of the Alardinskaya mine of the Kemerovo region (sample B).

The coarse samples (diameter $=0.5 \mathrm{~mm}$ ), initially taken for the experiment, were ground in a rattler in accordance with the following regime: the ratio of the grinding medium to the fuel was $1: 1$; the grinding duration was $9 \mathrm{~h}$; the resultant was sieved to obtain a fraction $<80 \mu \mathrm{m}$. The particle size distribution of coal samples was defined using an Analysette 22 laser diffraction particle analyzer (Fritsch, Germany).

Sieved coal powders were dried at $105{ }^{\circ} \mathrm{C}$ to constant weight. The technical characteristics of the samples were determined using standard methods (Tabakaev et al. 2019). The mass fraction of the main elements in the samples $(C$, $\mathrm{H}, \mathrm{N}, \mathrm{S}, \mathrm{O}$ ) was determined using the element analyzer Euro EA 3000 (EuroVector, Italy).

Scanning microscopy research was performed using an SEM JSM-6460LV instrument (JEOL, Japan) with an ionic focused beam. The values of pore volume and average pore size were determined by means of low-temperature nitrogen adsorption (BET method) using automatic gas-adsorption analyzer 3Flex (Micromeritics, USA).

\subsection{Introduction of the activating additives}

Crystalline hydrates of the following copper salts were taken as the activating additives: $\mathrm{Cu}\left(\mathrm{NO}_{3}\right)_{2} \cdot 3 \mathrm{H}_{2} \mathrm{O}$, $\mathrm{CuSO}_{4} \cdot 5 \mathrm{H}_{2} \mathrm{O}$, and $\mathrm{Cu}\left(\mathrm{CH}_{3} \mathrm{COO}\right)_{2} \cdot \mathrm{H}_{2} \mathrm{O}$. A brief description of the starting compounds is presented in Table 1.

An incipient wetness impregnation procedure was used to introduce the activating additives to the coal samples (Tokareva et al. 2014). A water-ethanol solution with a volumetric ratio of $\mathrm{C}_{2} \mathrm{H}_{5} \mathrm{OH} / \mathrm{H}_{2} \mathrm{O}=50 / 50$ was used for the impregnation, which made it possible to overcome the problem of the hydrophobicity of the pristine coal samples. 
Table 1 Characteristics of the starting chemicals (Wayne 2005)

\begin{tabular}{llll}
\hline Additive & $\begin{array}{l}\text { Molar } \\
\text { mass } \\
(\mathrm{g} / \mathrm{mol})\end{array}$ & $\begin{array}{l}\text { Decomposition } \\
\text { temperature } \\
\left({ }^{\circ} \mathrm{C}\right)\end{array}$ & $\begin{array}{l}\text { Solubility in } \\
\text { water }(\mathrm{g} / 100 \mathrm{~g} \text { of } \\
\text { solvent })\end{array}$ \\
\hline $\mathrm{Cu}\left(\mathrm{NO}_{3}\right)_{2} \cdot 3 \mathrm{H}_{2} \mathrm{O}$ & 241.6 & 170 & 124.7 \\
$\mathrm{CuSO}_{4} \cdot 5 \mathrm{H}_{2} \mathrm{O}$ & 249.7 & 650 & 32.6 \\
$\mathrm{Cu}\left(\mathrm{CH}_{3} \mathrm{COO}\right)_{2} \cdot \mathrm{H}_{2} \mathrm{O}$ & 199.6 & 290 & 7.2 \\
\hline
\end{tabular}

The moisture capacity of the dried coal samples (in $\mathrm{mL} / \mathrm{g}$ ) was measured before the impregnation procedure.

Based on the moisture capacity data, the required amount of the initial salts to be dissolved in a $\mathrm{C}_{2} \mathrm{H}_{5} \mathrm{OH} /$ $\mathrm{H}_{2} \mathrm{O}$ mixture was defined. The obtained solutions were used to impregnate the coal powders. The prepared samples were kept in an oven at $105{ }^{\circ} \mathrm{C}$ for $20 \mathrm{~h}$. The concentration of additives in all the samples (in terms of dry salt) was 5 wt $\%$. For comparative analysis, the reference samples free of additives were also prepared by the same preparative procedures. The list of the prepared samples and their labels are given in Table 2.

\subsection{Thermogravimetric and mass-spectrometric analyses}

The oxidation of the modified coal samples was studied using an STA 449 C Jupiter simultaneous thermal analyzer (Netzsch, Germany). All experiments were carried out at a heating rate of $2.5^{\circ} \mathrm{C} / \mathrm{min}$ in a corundum crucible with a perforated lid within a temperature range of $45-600{ }^{\circ} \mathrm{C}$. A sample of $15 \mathrm{mg}$ was placed into the crucible and purged with air with a volumetric flow rate of $60 \mathrm{~mL} / \mathrm{min}$. In some cases, the refining experiments in an inert atmosphere (nitrogen) at a gas flow rate of $60 \mathrm{~mL} / \mathrm{min}$ were also performed. All the TG experiments were conducted under atmospheric pressure. In order to define the kinetic characteristics of the activated oxidation process, it was

Table 2 The list of synthesized samples and their labels

\begin{tabular}{ll}
\hline Additive & Molar mass $(\mathrm{g} / \mathrm{mol})$ \\
\hline Lignite of Borodinskiy opencast coal mine & \\
Initial sample & $\mathrm{L}$ \\
$\mathrm{L}+5 \% \mathrm{Cu}\left(\mathrm{NO}_{3}\right)_{2}$ & $\mathrm{~L} / 1$ \\
$\mathrm{~L}+5 \% \mathrm{CuSO}$ & $\mathrm{L} / 2$ \\
$\mathrm{~L}+5 \% \mathrm{Cu}\left(\mathrm{CH}_{3} \mathrm{COO}\right)_{2}$ & $\mathrm{~L} / 3$ \\
Bituminous coal of Alardinskaya mine & \\
Initial sample & $\mathrm{B}$ \\
$\mathrm{B}+5 \% \mathrm{Cu}\left(\mathrm{NO}_{3}\right)_{2}$ & $\mathrm{~B} / 1$ \\
$\mathrm{~B}+5 \% \mathrm{CuSO}$ & $\mathrm{B} / 2$ \\
$\mathrm{~B}+5 \% \mathrm{Cu}\left(\mathrm{CH}_{3} \mathrm{COO}\right)_{2}$ & $\mathrm{~B} / 3$ \\
\hline
\end{tabular}

realized at different heating rates of $2.5,10,25$ and $40{ }^{\circ} \mathrm{C} /$ min in a temperature range of $45-1000{ }^{\circ} \mathrm{C}$.

For all the sample series, a qualitative analysis was carried out to determine the composition of the gaseous products at the outlet of the thermal analyzer chamber. The analysis was performed using a QMS 403 D Aeolos coupled quadrupole mass spectrometer (Netzsch, Germany).

\subsection{Definition of the kinetic characteristics of the coal oxidation process}

A comparative assessment of the coal oxidation parameters was carried out on the basis of physical characteristics (temperature, time, and oxidation rate), which were calculated by the graphical method (Zou et al. 2016) from experimental TG and DTG curves (Fig. 1).

Points $A$ and $B$ on the TG curve characterize the onset temperature $\left(T_{\mathrm{i}}\right)$ and the temperature of completion of the oxidation process $\left(T_{\mathrm{f}}\right)$, respectively. Point $C$ at the extremum on the DTG curve represents the maximum value of the weight loss rate $\left(w_{\max }\right)$ at the corresponding

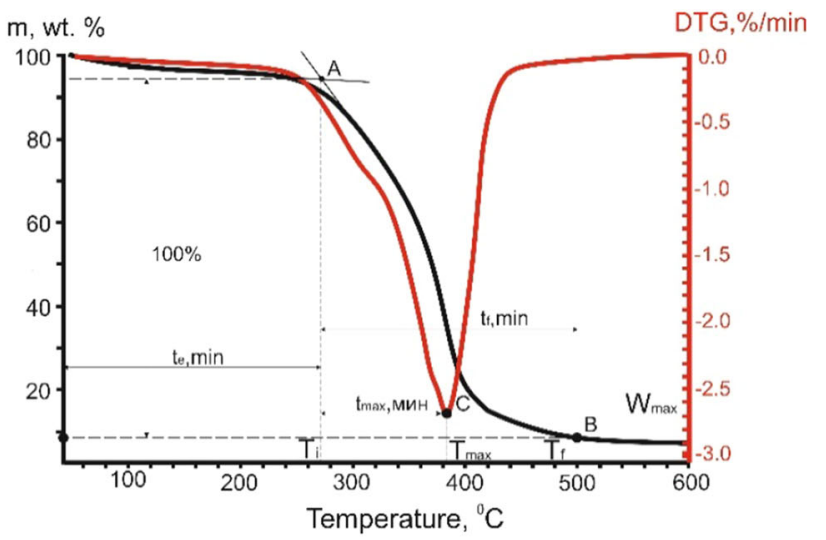

(a)

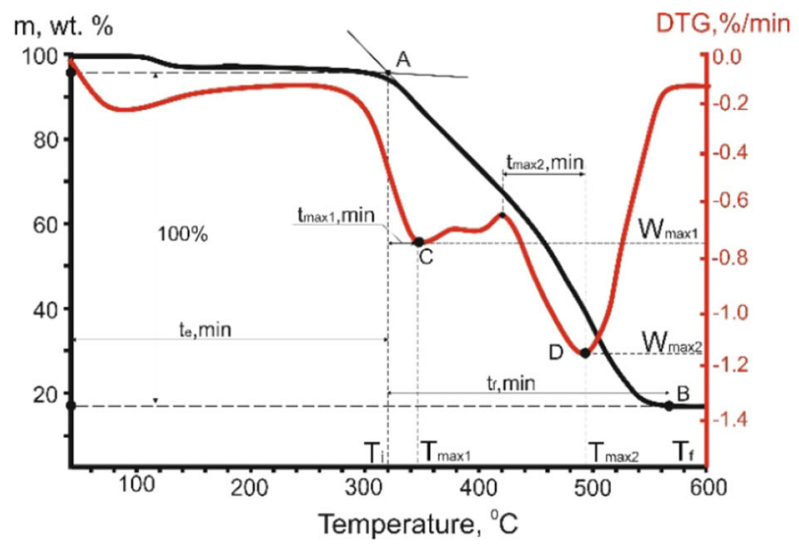

(b)

Fig. 1 The principle parameters for the oxidation of lignite a and bituminous coal $\mathbf{b}$ to be defined from TGA and DTG data 
temperature $\left(T_{\max }\right)$. Based on the obtained temperature values, the following time parameters of the oxidation process were determined: $t_{\mathrm{e}}$ (time of heating up to $T_{\mathrm{i}}$ ) and $t_{\mathrm{f}}$ (complete time of the sample oxidation). In the case of the bimodal shaped DTG curves, an additional point $D$ was introduced with corresponding maximum reaction rate and characteristic temperature $\left(w_{\max 2}\right.$ and $\left.T_{\max 2}\right)$.

The dependence of the activation energy of the oxidation process $\left(E_{\mathrm{a}}\right)$ on the conversion was determined using the Friedman method (Kok 2002; Xie and He 1998; Santos et al. 2007; Coats and Redfern 1964; Vyazovkin et al. 2011). The differential Friedman method only was applied because, according to our earlier studies, the significant variation of activation energy values was expected (Slyusarskiy et al. 2017). While the difference between maximal and minimal activation energy values was expected to be larger than $40 \%$, the integral methods were not used according to recommendations of the ICTAC committee (Vyazovkin et al. 2011). This method is based on the following expression obtained by transforming the Arrhenius equation:

$\ln \left(\frac{\mathrm{d} \alpha}{\mathrm{d} t}\right)_{\alpha, i}=\ln \left[f(\alpha) \cdot A_{\alpha}\right]-\frac{E_{\alpha}}{R T_{\alpha, i}}$

where $\left(\frac{\mathrm{d} \alpha}{\mathrm{d} t}\right)$ is the rate of sample conversion at conversion degree and heating rate; $f(\alpha)$ is the value of the kinetic function at conversion degree; $A_{\alpha}$ is frequency factor at conversion degree; $E_{\alpha}$ is activation energy at conversion degree, $\mathrm{J} / \mathrm{mol} ; R$ is universal gas constant; $T_{\alpha, i}$ is sample temperature at conversion degree and heating rate.

The values of the kinetic constants corresponding to a fixed degree of conversion were determined using the linear approximation constants of the experimental dependence of $\ln \left(\frac{\mathrm{d} \alpha}{\mathrm{d} t}\right)$ on $\frac{1}{T}$. The frequency factor values were calculated using a kinetic model of the first-order reaction (Vyazovkin et al. 2011): $f(\alpha)=(1-\alpha)$. The conversion dependences of the kinetic parameters were determined within a conversion range of $0.05-0.95$ with an increment of 0.05 , according to the recommendations reported elsewhere (Vyazovkin et al. 2011). In order to exclude the possible effects of the stages connected to the humidity removal, the kinetic characteristics for the activated oxidation process were defined in a temperature range of $150-1000{ }^{\circ} \mathrm{C}$.

\section{Results and discussion}

\subsection{Characteristics of initial and modified samples}

The properties of the initial coal samples subjected to a milling procedure and dried at $105{ }^{\circ} \mathrm{C}$ are presented in
Table 3. The characteristic differences in the chemical composition of the studied samples should be noted. Thus, there is a high content of volatile matter (about 40\%) and a relatively low ash yield (less than $5 \mathrm{wt} \%$ ) in lignite that is associated with its low degree of carbonization. In its turn, the bituminous coal sample has a rather low content of volatile matter (about 13\%) and higher ash yield (about 17\%) and fixed carbon (about 70\%).

Samples are also different in terms of the particle size distribution $\left(X_{50}=13.9-20.4 \mu \mathrm{m}\right)$ that could be explained by certain differences in their morphology (Fig. 2) (Sriramoju et al. 2019). Despite the low porosity (less than $0.03 \mathrm{~cm}^{3} / \mathrm{g}$ ), this material is characterized by quite high moisture capacity, which makes it possible to deposit the highly soluble copper salts by the impregnation in one stage (Table 3).

The scanning electron microscopy (SEM) micrographs of the pristine coal samples are presented in Fig. 2. One can see that the powders of coal consist of faceted irregular particles with a heterogeneous surface and contained many smaller fragments that were less than $5 \mu \mathrm{m}$ in size. It is important to note that the sample of bituminous coal, in contrary with lignite one, has a more dense and uniform surface structure.

Table 3 Characteristics of the pristine coal samples after drying at $105{ }^{\circ} \mathrm{C}$ for $20 \mathrm{~h}$

\begin{tabular}{lcc}
\hline Parameter & Sample \\
\cline { 2 - 3 } & $\mathrm{L}$ & $\mathrm{B}$ \\
\hline Ash yield (wt\%) & 4.5 & 16.5 \\
Humidity (wt\%) & 1.0 & 0.3 \\
Volatile matter content $(\mathrm{wt} \%)$ & 39.8 & 13.1 \\
Fixed carbon content $(\mathrm{wt} \%)$ & 54.7 & 70.1 \\
Moisture-holding capacity ${ }^{\mathrm{a}}(\mathrm{mL} / \mathrm{g})$ & 3.4 & 2.6 \\
Elemental composition $(\mathrm{wt} \%)$ & & \\
$\mathrm{C}$ & 64.7 & 80.0 \\
$\mathrm{H}$ & 4.6 & 2.2 \\
$\mathrm{~N}$ & 1.5 & 2.5 \\
$\mathrm{~S}$ & $<1$ & $<1$ \\
O & 28.2 & 14.3 \\
Particle size distribution $(\mu \mathrm{m})$ & & \\
$X_{10}$ & 2.8 & 4.6 \\
$X_{50}$ & 13.9 & 20.4 \\
$X_{90}$ & 34.8 & 57.6 \\
Average particle diameter $(\mathrm{nm})$ & $18.3 \pm 0.07$ & $26.5 \pm 0.09$ \\
Porosity & & \\
Average pore size $(\mathrm{nm})$ & 20.5 & 11.9 \\
Overall pore volume $\left(\mathrm{cm}{ }^{3} / \mathrm{g}\right)$ & 0.03 & 0.01 \\
\hline
\end{tabular}

${ }^{\mathrm{a}}$ measured for water-ethanol solvent $\left(\mathrm{H}_{2} \mathrm{O} / \mathrm{C}_{2} \mathrm{H}_{5} \mathrm{OH}=50 / 50\right)$ 


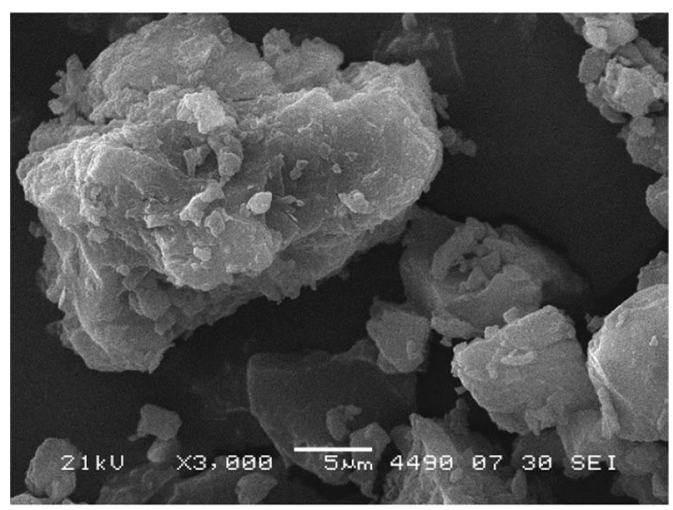

(a)

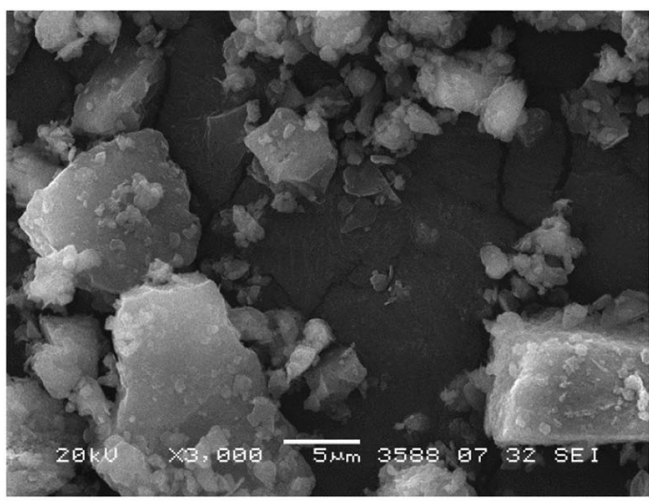

(b)

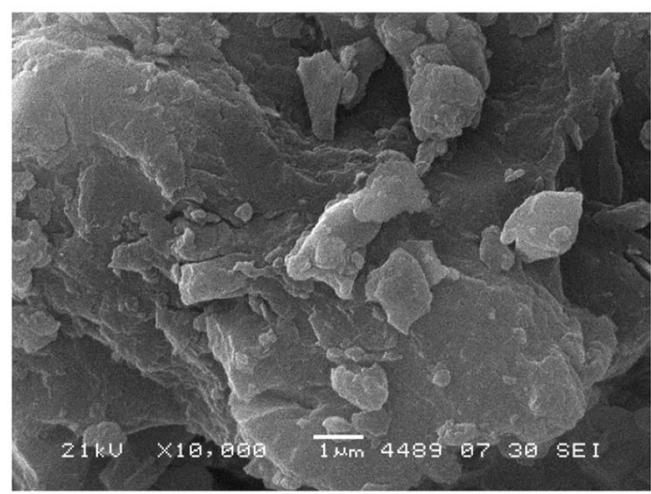

(c)

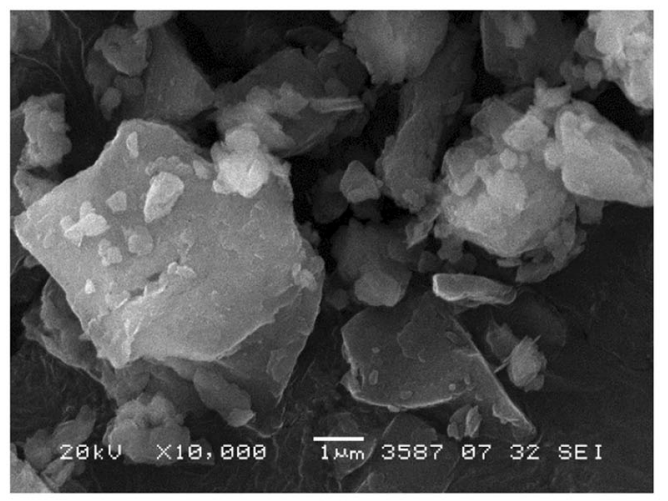

(d)
Fig. 2 SEM images of the pristine coal samples: a, c refer to sample L; b, $\mathbf{d}$ refer to sample B

As it was reported in our previous work (Larionov and Gromov 2019), where the results of EDX mapping were presented, an introduction of salt by the impregnation method (for the case of the lignite sample modified by $\left.\mathrm{Cu}\left(\mathrm{NO}_{3}\right)_{2}\right)$ provides a fairly uniform distribution of the activating additive throughout the surface of the coal particles. The results revealed that the uniform character of copper distribution in the structure of the ash residue has remained after the combustion of the samples (Larionov and Gromov 2019).

\subsection{Effect of activation additives on coal oxidation characteristics}

The results of the experimental study on the oxidation of the samples by the TGA technique are presented in Fig. 3 .

It was established that in all cases, the deposition of copper salts has a rather significant activating effect, which is expressed in a decreased value of the initial temperature of coal oxidation $\left(T_{\mathrm{i}}\right)$. At the same time, the oxidation process has a very similar character for all the studied samples modified with the addition of copper salts.

As it can be seen from Fig. 3, the weight loss of the pristine coal samples proceeds basically in four stages: desorption of moisture (till $100{ }^{\circ} \mathrm{C}$ ); thermal decomposition of particles with the release of volatile components (100-310 $\left.{ }^{\circ} \mathrm{C}\right)$; oxidation of volatile compounds after their release $\left(228-360^{\circ} \mathrm{C}\right)$; and oxidation of the coke residue (in a temperature range of $320-590{ }^{\circ} \mathrm{C}$ ). At the 1 st stage of the heating process, the weight loss did not exceed $2 \%$, which is explained by the fact that the samples were dried before the measurements. As it was already mentioned above, the second stage starts from the endothermic process of the coal decomposition and completes with the intensive oxidation of volatile matter released from the coal particles. This stage occurs in parallel with the 3rd one, during which the thermal decomposition of the particles continues with the release of more volatile compounds. A significant change in the structure of the reacting part of the fuel with the expansion of internal cracks and pores takes place in the course of the stages $1-3$. This process is accompanied by an intensification of the interaction of the cracked surface of coal with the oxidizing atmosphere.

As it follows from the shape of DTG curves, the character of the transition between the 3rd and 4th stages depends on the type of coal having different content of volatile matter and carbon (Table 3). This is the most pronounced for samples of lignite, where the oxidation of 


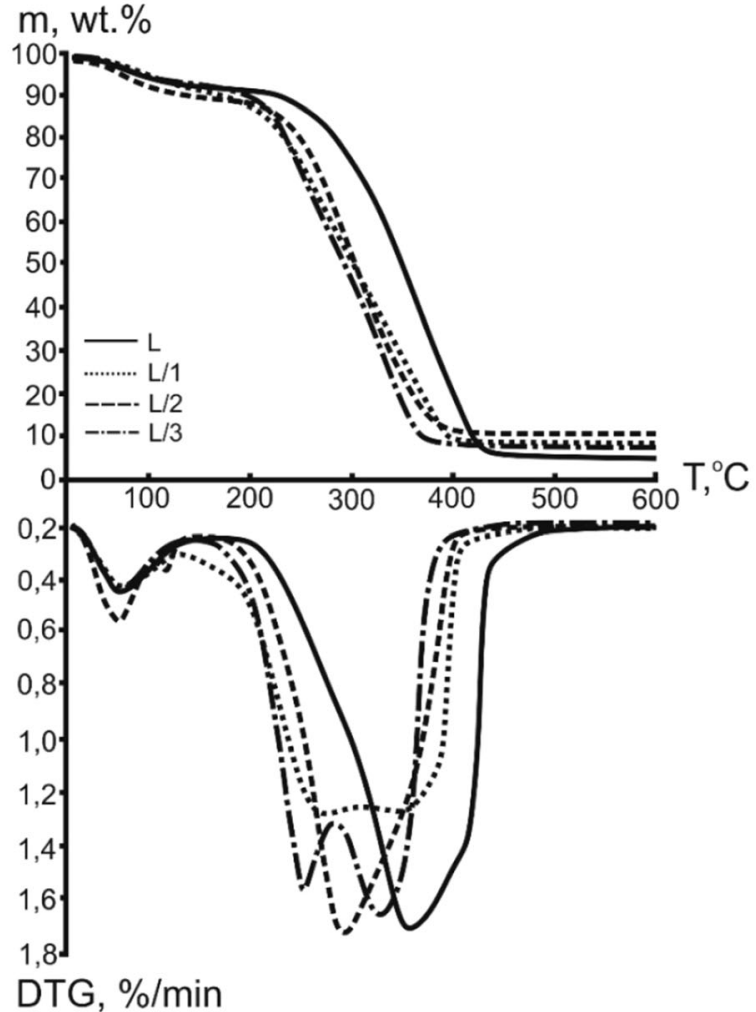

(a)

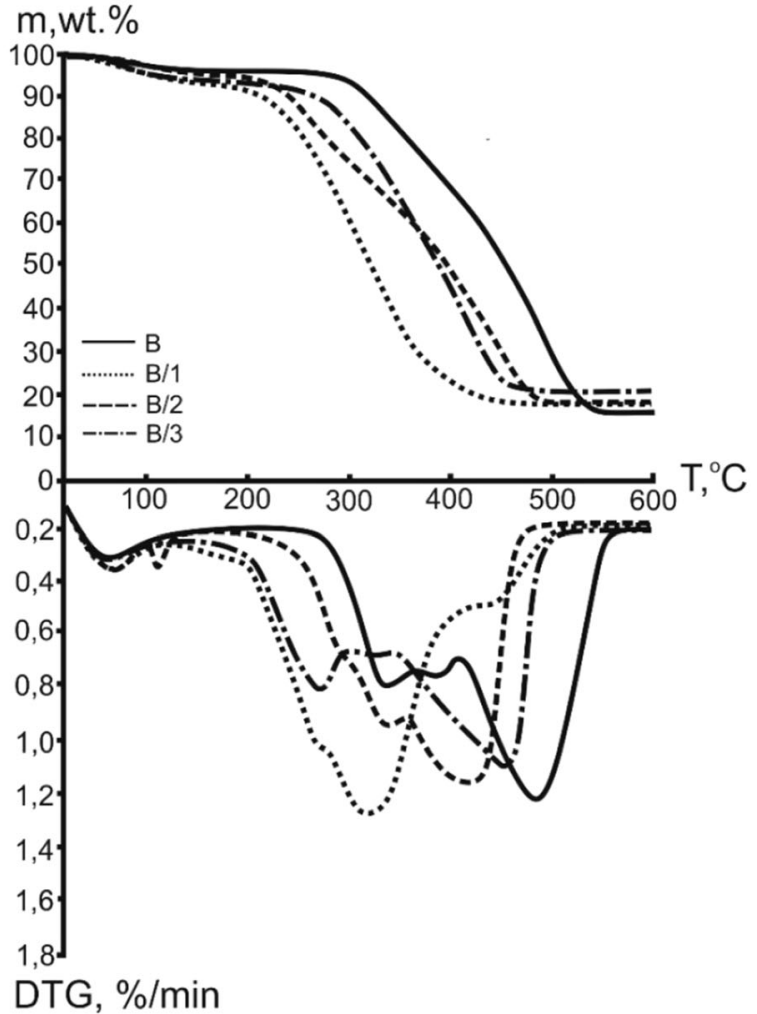

(b)

Fig. 3 TG- and DTG-curves for the oxidation of energetic coals modified with copper salts: a L series; $\mathbf{b} \mathrm{B}$ series. The flow rate is $60 \mathrm{~mL} / \mathrm{min}$ (air), the heating rate is $2.5^{\circ} \mathrm{C} / \mathrm{min}$, the temperature range is $45-600{ }^{\circ} \mathrm{C}$, the sample loading is about $17 \mathrm{mg}$

the resulting coke residue occurs in parallel with the burning of the released hydrocarbons.

The L-sample of lignite showed the lowest initial oxidation temperature (about $240{ }^{\circ} \mathrm{C}$ ). The B-sample of bituminous coal, in its turn, is characterized by a lower content of volatile matter and a later stage of their release, which therefore resulted in the higher oxidation onset temperature $\left(310^{\circ} \mathrm{C}\right)$. The complete loss of the combustible mass of the L-samples takes place at temperatures about $420{ }^{\circ} \mathrm{C}$; for $\mathrm{B}$-samples, this temperature is near $590{ }^{\circ} \mathrm{C}$. The difference in the values of $T_{\mathrm{i}}$ and $T_{\mathrm{f}}$ is assumed to be caused by the current difference in the content of volatile matter and carbon in the composition of the initial samples (Table 3).

The rate of volatile matter release strongly depends on the initial morphology of the coal. So, the lignite characterized by the heterogeneous structure and large volume of the internal pores (Fig. 1, Table 3) is more susceptible to the intense process of internal thermal decomposition, causing the promoted release of the volatile matter with their subsequent oxidation (Senneca et al. 2017).

It also can be seen from Fig. 3 that all the samples modified by the addition of copper salts have a different character and shape of the TG and DTG curves if compared with the reference sample free of additives. For samples modified by the addition of $\mathrm{CuSO}_{4} \cdot 5 \mathrm{H}_{2} \mathrm{O}$, the appearance of an additional peak in the region of $120^{\circ} \mathrm{C}$ can be observed on the DTG curves that can be explained by the dehydration of salt and corresponding formation of monohydrate. In the temperature region corresponding to the volatile matter release for modified samples (for L-series: about $180-250{ }^{\circ} \mathrm{C}$, for B-series: $210-300{ }^{\circ} \mathrm{C}$ ), the observed weight loss is substantially greater, in contrast to the reference samples. It could be explained by the complete or partial decomposition of salts. As it was already reported (Larionov et al. 2019), the decomposition of salts present in the structure of coal particles promotes a significant shift of $T_{\mathrm{i}}$ to the low-temperature region.

It should also be noted that DTG curves for samples L/1 and $L / 3$ indicate the bimodal nature of the oxidation process (Fig. 3). Most likely, this is due to the intensification of oxidation of the volatile matter released from the surface of the particles in the low-temperature region of $210-290{ }^{\circ} \mathrm{C}$.

For lignite samples, the maximum decrease in the $T_{\mathrm{i}}$ parameter is observed for the L/1 sample, while the minimal effect was recorded for the sample modified by the $\mathrm{CuSO}_{4}$ additive. For the samples of bituminous coal, the 
addition of $\mathrm{CuSO}_{4}$ demonstrated moderate activity in comparison with other studied series of promoters.

Thus, the analysis of the influence of copper salt additives with different compositions on the acceleration of the lignite oxidation process allows one to suggest the following activity row: $\mathrm{Cu}\left(\mathrm{NO}_{3}\right)_{2}>\mathrm{Cu}\left(\mathrm{CH}_{3} \mathrm{COO}\right)_{2}>$ $\mathrm{CuSO}_{4}$. The activity order for the bituminous coal would be as follows: $\mathrm{Cu}\left(\mathrm{NO}_{3}\right)_{2}>\mathrm{CuSO}_{4}>\mathrm{Cu}\left(\mathrm{CH}_{3} \mathrm{COO}\right)_{2}$.

Figure 4 presents a summary diagram showing the effect of activating additives on the parameter $\Delta T_{\mathrm{i}}$ (change in the initial temperature of active oxidation) for both types of coal. It is seen that the highest $\Delta T_{\mathrm{i}}$ values $\left(52{ }^{\circ} \mathrm{C}\right.$ and $94{ }^{\circ} \mathrm{C}$ ) were observed for the coal samples modified with copper nitrate ( $\mathrm{L} / 1$ and $\mathrm{B} / 1$, respectively).

It should be noted that the result obtained is also consistent with the literature data (Gong et al. 2010a), where an enhancement of the positive effect of the activating additive along with the increase in the carbon content in the sample was shown. The molecular structure of lignite, in contrast to the bituminous coal, is characterized by the greater number of lateral and bridging bonds that are susceptible to decomposition at a relatively low temperature. In particular, this refers to the active O-containing functional groups: $-\mathrm{OCH}_{3},-\mathrm{OH},-\mathrm{COOH},-\mathrm{C}=\mathrm{O}$ (Zhang et al. 2017; Liu et al. 2016; Wang et al. 2016). With an increase in the coal rank, the concentration of the functional groups is decreased, and the activating additives mainly affect the kinetics of the chain oxidation reaction during thermal heating.

\subsection{Mass-spectrometry analysis results}

The mass spectrometry profiles for the $\mathrm{NO}_{x}(m / z=30)$ and $\mathrm{CO}_{2}(\mathrm{~m} / z=44)$ concentration in released gas-phase products during oxidation of the modified samples are presented in Fig. 5. For the convenience of comparison, MS-analysis

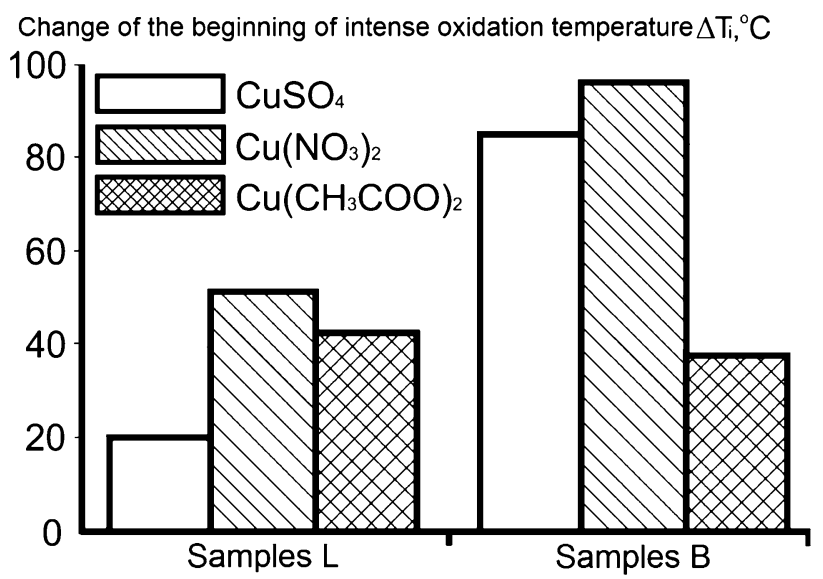

Fig. 4 The effect of the activating additive type on the change in the initial oxidation temperature $\left(\Delta T_{\mathrm{i}}\right)$ for modified coal samples data are presented together with the results of DTG analysis in Fig. 5. It could be seen that for all the samples containing promoter additive, a release of $\mathrm{NO}_{x}$ and $\mathrm{CO}_{2}$ (corresponding to oxidation products of additive decomposition) in a temperature range of $130-480{ }^{\circ} \mathrm{C}$ takes place. The lower graph in Fig. 5 represents the mass spectrometric data on the nitrogen oxides $\mathrm{NO}_{x}(\mathrm{~m} / \mathrm{z}=30)$ release for the different additives.

Regardless of the type of coal, an introduction of copper nitrate causes significant changes in the MS profile. First of all, the emergence of an intense broad peak in the lowtemperature region $\left(190-220{ }^{\circ} \mathrm{C}\right)$ for all the studied coal samples, which is obviously associated with decomposition of the additive (Fig. 5), should be noted. The character of the $\mathrm{NO}_{x}$ release indicates that the decomposition of $\mathrm{Cu}\left(\mathrm{NO}_{3}\right)_{2}$ had already begun at the temperatures close to $130{ }^{\circ} \mathrm{C}$, thus indicating a certain degree of the carrier (coal) participation in this process (Ruiz et al. 2010).

TG and DTG curves in Fig. 6 illustrate the process of thermal decomposition of the $5 \mathrm{wt} \% \mathrm{Cu}\left(\mathrm{NO}_{3}\right)_{2}$ salt deposited on an inert carrier $\left(\alpha-\mathrm{Al}_{2} \mathrm{O}_{3}\right)$ as well as that of modified samples $\mathrm{L} / 1$ and $\mathrm{B} / 1$. The supplement experiments were performed in an inert medium (nitrogen) in order to exclude the possible influence of the oxidizing atmosphere on the thermal decomposition of copper nitrate supported on a carbon substrate. It could be seen that there is a shift to lower temperatures for the modified samples $\mathrm{L} /$ 1 and $\mathrm{B} / 1$, unlike the sample with the additive (copper nitrate) deposited on an inert carrier $\left(\alpha-\mathrm{Al}_{2} \mathrm{O}_{3}+\mathrm{Cu}\left(\mathrm{NO}_{3}\right)\right)$ $\longrightarrow \Delta T_{\mathrm{i}}=22^{\circ} \mathrm{C} \mathrm{L} / 1 \longrightarrow \Delta T_{\mathrm{i}}=16^{\circ} \mathrm{C} \mathrm{B} / 1$. Thus, the results obtained are consistent with the data presented in Fig. 5.

The second (less intense) stage of $\mathrm{NO}_{x}$ emission is related to the formation of nitrogen oxides during the coke residue combustion due to the involvement of molecular nitrogen $\mathrm{N}_{2}$ in the oxidation process (Fig. 5). It should be emphasized that in this case, the second peak $\Delta T_{\mathrm{NO}_{2}}$ was also moved to a lower temperature region, the magnitude of which depends on the nature of the activating additive. It is important to note that this process is accompanied by a noticeable decrease in the intensity of the $\mathrm{NO}_{x}$ formation, which is evident if compared to the data in Fig. 5.

Thereby, the nitrogen oxides $\mathrm{NO}_{x}$ species resulted from the decomposition of the coal-supported nitrate might be responsible for the significant acceleration of the coal oxidation process (Wang et al. 2015a, b) and initiation of the early release of the volatile matter and their subsequent oxidation. A comparison of the DTG and MS-analysis results (Fig. 5) allows one to conclude that the temperature shift of the oxidation onset $\Delta T_{\mathrm{i}}$ is directly connected to the decomposition temperature of the corresponding metal nitrates. The possible mechanism of the $\mathrm{Cu}\left(\mathrm{NO}_{3}\right)_{2}$ activating additive action during the coal oxidation has already been reported (Larionov and Gromov 2019). The first stage 

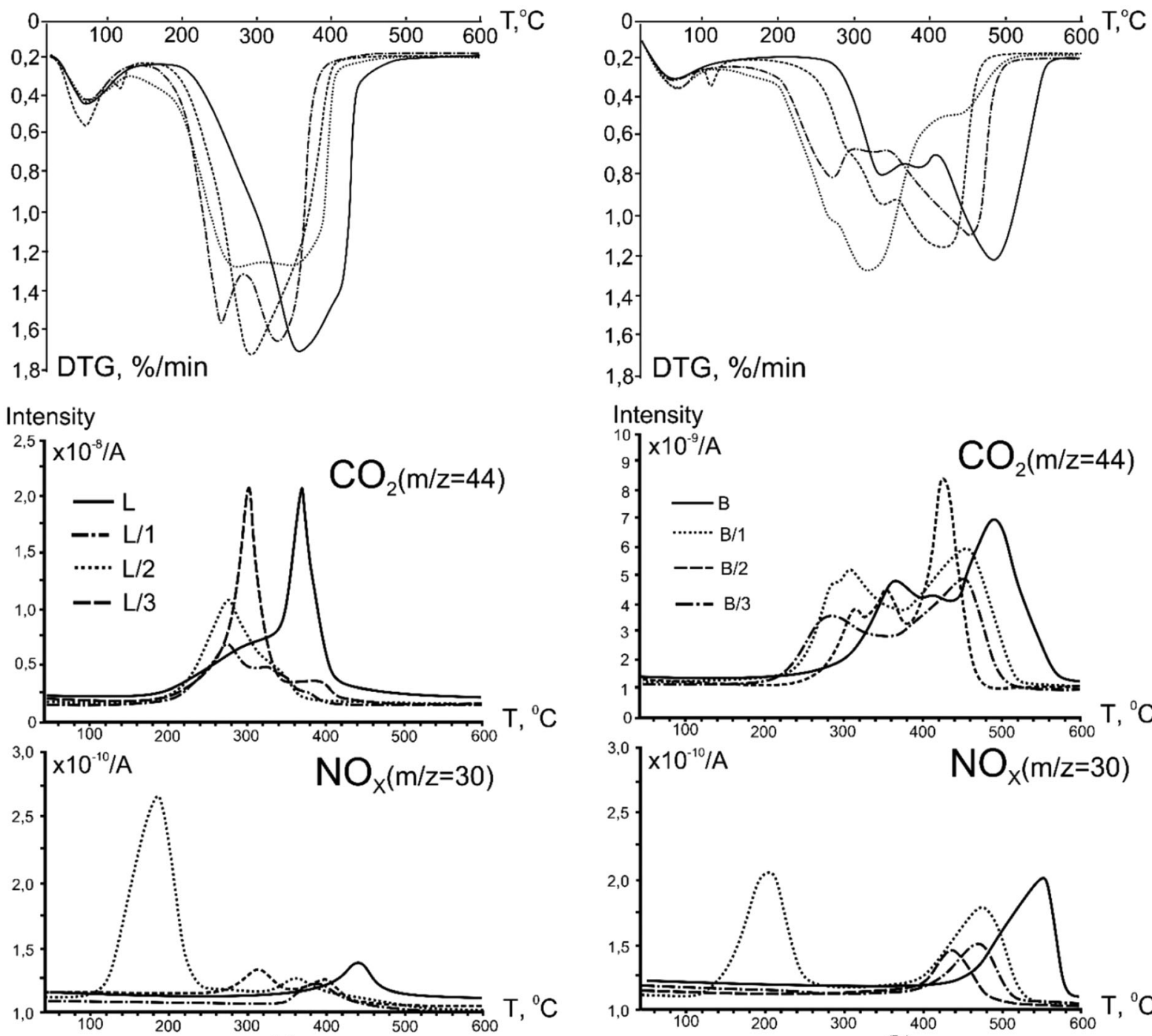

(a)

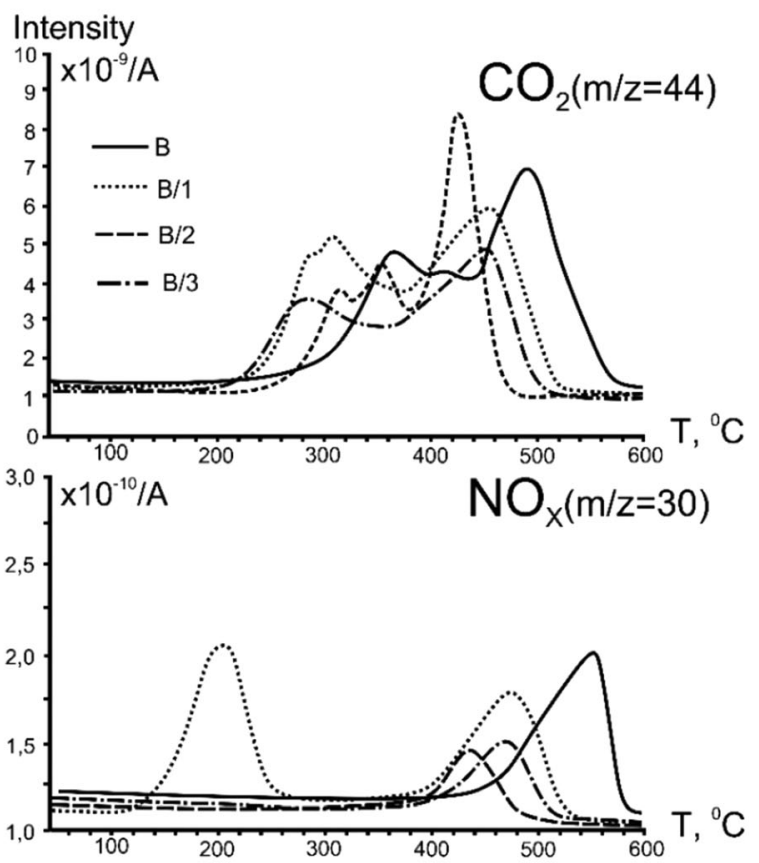

(b)

Fig. 5 MS profiles of $\mathrm{NO}_{x}$ and $\mathrm{CO}_{2}$ emission $\mathbf{a}$ and $\mathbf{b}$ samples of lignite and bituminous coal, respectively). The air flow rate was $60 \mathrm{~mL} / \mathrm{min}$; the heating rate was $2.5^{\circ} \mathrm{C} / \mathrm{min}$; the temperature range was $45-600^{\circ} \mathrm{C}$; the sample loading was about $17 \mathrm{mg}$

of the transformation is associated with the decomposition of copper nitrate (in a temperature range of $130-170{ }^{\circ} \mathrm{C}$ ) and the formation of nitrogen oxides. Thus formed $\mathrm{NO}_{2}$ could act as a strong oxidizing agent during the oxidation of volatile matter and coke residue (Shao et al. 2016; Wang et al. 2015a, b).

After completion of the $\mathrm{Cu}\left(\mathrm{NO}_{3}\right)_{2}$ decomposition, the dispersed non-stoichiometric copper oxide is formed. It may be composed of a set of different oxide phases: $\mathrm{CuO}$, $\mathrm{Cu}_{2} \mathrm{O}$, and $\mathrm{Cu}_{2} \mathrm{O}_{3}$. However, a further temperature increase to the values above $400{ }^{\circ} \mathrm{C}$ in the oxygen-containing atmosphere results in the stabilization of a single phase of copper oxide $(\mathrm{CuO})$. At the same time, the copper oxide formed during the above-mentioned reactions (Chen et al. 2008) is known to be a very active oxidation catalyst in various processes of heterogeneous catalysis. Thus, the presence of the dispersed $\mathrm{CuO}$ particles on the surface of coal might be considered as another factor accelerating its oxidation.

There are two types of interaction of copper sulfate with the coal, which could be considered. The first type is related to reactions of small fragments of the additive with the active oxygen-containing functional groups of the coal (Lin et al. 2012) (which are released in the form of hydrocarbons during the heating). The second type already mentioned above takes place during the close contact of the formed catalytic particles $\mathrm{CuO}_{x}$ with the coke residue.

It was assumed that the release of $\mathrm{SO}_{2}$ during the partial decomposition of $\mathrm{CuSO}_{4}$ on the carbon substrate could contribute to the activation of the volatile matter release and their further partial or complete oxidation (depending on the reaction medium). As a result, the more intense $\mathrm{CO}_{2}$ 


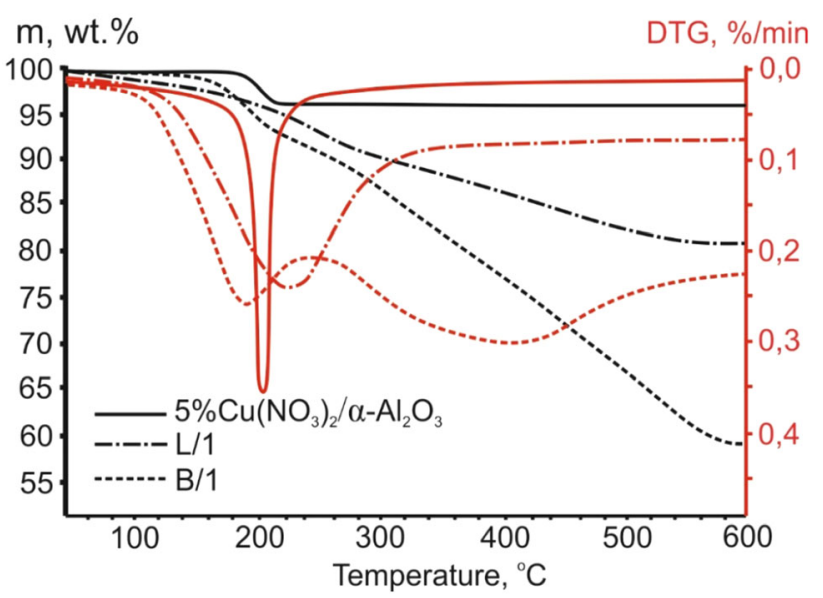

Fig. 6 TG- and DTG-curves of the thermal decomposition of copper nitrate and energetic coals. The nitrogen flow rate was $60 \mathrm{~mL} / \mathrm{min}$; the heating rate was $2.5^{\circ} \mathrm{C} / \mathrm{min}$; the sample loading was about $17 \mathrm{mg}$

emissions are well seen in Fig. 5 as the more broad peaks on the corresponding DTG-curves (Fig. 4).

For the samples modified by the addition of copper acetate, the process of carbon dioxide release $(\mathrm{m} / \mathrm{z}=44)$ the main oxidation product of a combustible substance-is characterized by a bimodal character (Fig. 5). The shape of the MS profile for $\mathrm{CO}_{2}$ replicates the corresponding DTG curves (Fig. 4): it includes both the processes of $\mathrm{Cu}\left(\mathrm{CH}_{3}\right.$ $\mathrm{COO})_{2}$ salt decomposition and the oxidation of the released volatile matter.

According to Lin et al. (2012), thermal decomposition of copper acetate monohydrate $\mathrm{Cu}\left(\mathrm{CH}_{3} \mathrm{COO}\right)_{2} \cdot \mathrm{H}_{2} \mathrm{O}$ in an oxygen-containing medium is accompanied by the loss of water at around $130{ }^{\circ} \mathrm{C}$ followed by the decomposition of salt in a temperature range of $220-300{ }^{\circ} \mathrm{C}$. The primary gas-phase products of $\mathrm{Cu}\left(\mathrm{CH}_{3} \mathrm{COO}\right)_{2}$ decomposition (vapors of acetone, acetaldehyde, and acetic acid) are further oxidized to carbon dioxide and water during interactions with atmospheric oxygen.

As the oxidation reactions of the gas-phase decomposition products of copper acetate are exothermic ones (Obaid et al. 2000), the generation of additional heat takes place. They contribute to earlier thermal decomposition of the coal particles, thus initiating the release of volatile matter (for samples $\mathrm{L} / 3 T_{\mathrm{i}}=213{ }^{\circ} \mathrm{C}$, for $\mathrm{B} / 3 T_{\mathrm{i}}=262{ }^{\circ} \mathrm{C}$ ).

\subsection{Effect of heating rate on the activating properties of additive (copper nitrate)}

Thermal analysis results for the initial and modified by copper nitrate coal samples at different heating rates are given in Figs. 7 and 8 in the form of TG and DTG curves.

As can be seen from Figs. 7 and 8, with increasing the heating rate, the oxidation process is shifted towards the high-temperature area for all the studied coal samples. As a result of the changing temperature regime of the process, the combustible mass of the samples was increased along with the average and maximal oxidation reaction rates. At the same time, the slope of TG-curves became more smooth (Fig. 7).

Changes in the TG-curves of the coal oxidation process are reflected in the DTG-curves (Fig. 8). It is well seen that with increasing the heating rate of the samples, the obtained DTG-curves change shape from bimodal to monomodal with a simultaneous increase of the reaction rate. The most obvious example is represented by $\mathrm{B}$ series samples (B/1). In their case, the first peak of volatile matter oxidation at the minimal heating rate $\left(2.5^{\circ} \mathrm{C} / \mathrm{min}\right)$ was transformed into the characteristic shoulder of monomodal extremum of the DTG-curve, which was obtained at the maximal heating rate $\left(40{ }^{\circ} \mathrm{C} / \mathrm{min}\right)$. At the same time, it is worth mentioning that increasing the heating rate resulted in an increased width of the DTG-curves.

For $\mathrm{B} / 1$ sample at the maximal heating rate $\left(40{ }^{\circ} \mathrm{C} / \mathrm{min}\right)$, the most significant change of $T_{\mathrm{i}}$ was observed $\left(115^{\circ} \mathrm{C}\right)$,

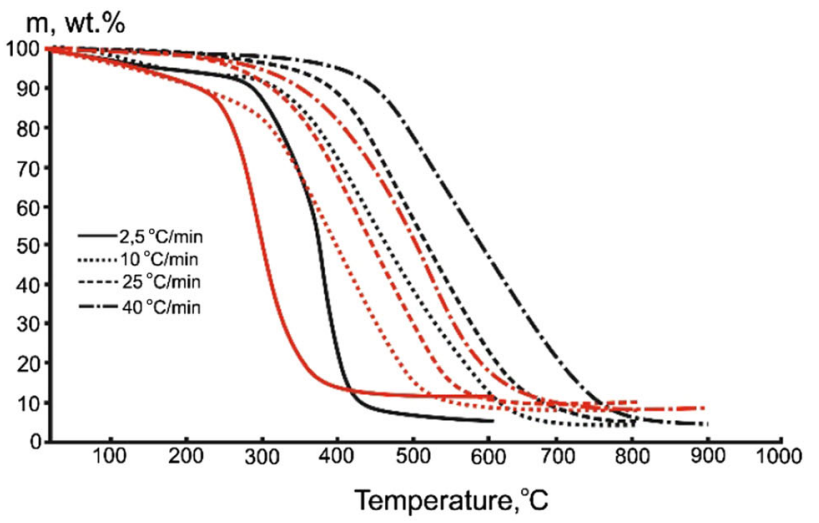

(a)

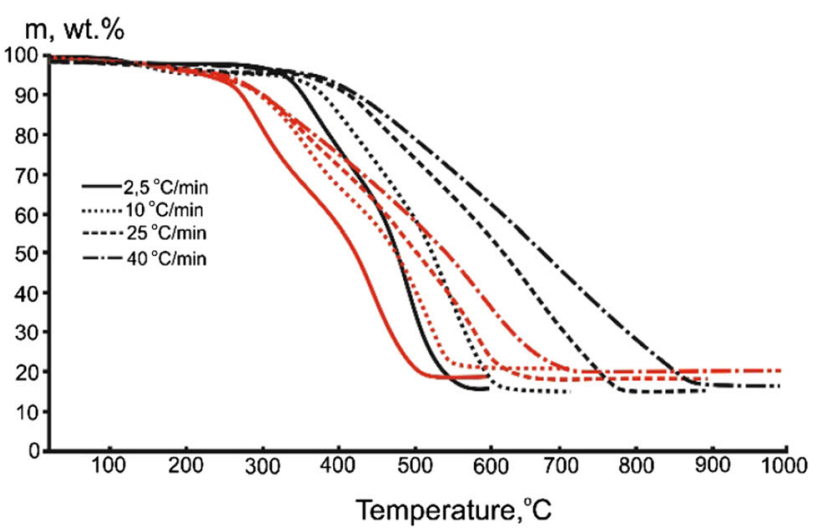

(b)

Fig. 7 TG-curves for the oxidation of the coal samples at different heating rates. a L series samples; b B series samples. Initial samples are denoted by a black line, the modified samples are denoted by a red line 


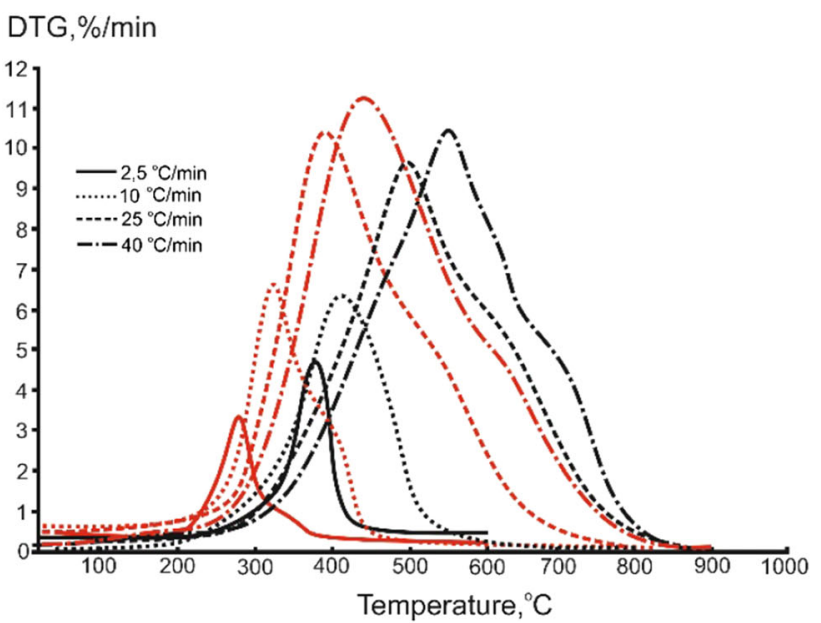

(a)

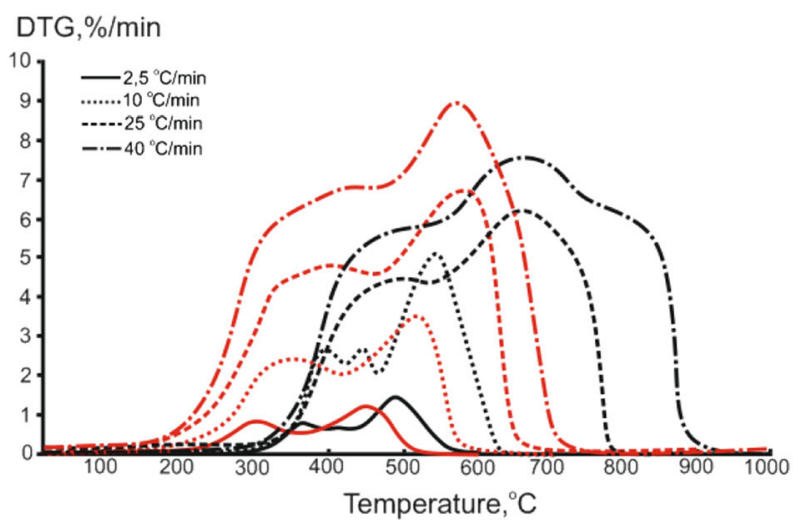

(b)

Fig. 8 DTG-curves for the oxidation of the coal samples at different heating rates. a $\mathrm{L}$ series samples; $\mathbf{b} \mathrm{B}$ series samples. Initial samples are denoted by a black line, the modified samples are denoted by a red line

while at a heating rate of $2.5^{\circ} \mathrm{C} / \min \Delta T_{\mathrm{i}}$ was $70{ }^{\circ} \mathrm{C}$. For $\mathrm{L} / 1$ sample at a maximal heating rate, $\Delta T_{\mathrm{i}}$ was found to be $75{ }^{\circ} \mathrm{C}$. The difference in a decrease in the oxidation completion temperature $\Delta T_{\mathrm{f}}$ has the same tendency as $T_{\mathrm{i}}$ parameter. The most significant decreasing of the $T_{\mathrm{f}}$ parameter $\left(180^{\circ} \mathrm{C}\right)$ was observed for $\mathrm{B} / 1$ sample at $40{ }^{\circ} \mathrm{C} /$ min heating rate. For $\mathrm{L} / 1$ sample at the same heating rate, this value was equal to $120^{\circ} \mathrm{C}$.

This effect can be explained by catalytic activation of formed non-stoichiometric copper oxide $\mathrm{CuO}_{x}$ at the hightemperature area of the process, which is achieved quicker with the high sample heating rate. The more intensive process of oxygen transfer in the system 'oxidizer-catalystsubstrate' leads to the maximal reaction rate of the formed residue carbon oxidation $w_{\max }$ (Fig. 8). It resulted in earlier completion of the modified sample thermal decomposition.

It is worth mentioning that with increasing the heating rate, the shift of temperature extremums $\Delta T_{\max 1}$ and
$\Delta T_{\max 2}$ corresponding to maximal reaction rate has nearly the same values.

\subsection{Evaluation of the parameters and kinetic characteristics of the coal oxidation}

The analysis of the oxidation characteristics (Table 4) indicates that the total oxidation time $t_{\mathrm{f}}$ of the combustible mass is being reduced with a decrease in the intense oxidation onset temperature $T_{\mathrm{i}}$ of the modified samples. It ultimately resulted in the shift of the process to the lowtemperature region. It is worth mentioning that the largest change in the rate of weight loss corresponds to the stages of volatile matter release and oxidation. A decrease in the initial temperature of intensive oxidation leads to a corresponding reduction of the total residence time of the samples in the temperature range of volatile matter release $t_{\mathrm{e}}$.

${ }^{\text {a }}$ These parameters were used in the case of the bimodalshaped DTG-curve. In the case of the monomodal-shaped curve, the following parameters were used for analysis: $T_{\max 1}, w_{\max 1}, t_{\max 1}$.

The dependences of activation energy on the conversion degree calculated by the Friedman method for the samples modified by copper nitrate (as the most active ones) are presented in Fig. 9. The determination coefficient for all the obtained approximation dependencies was above 0.99 .

For the L lignite sample (Fig. 9a), three characteristic stages can be distinguished: a sharp increase (in the conversion range of 0.05-0.10), a gradual decrease (from 0.15 to 0.70 ), and constant value (between 0.70 and 0.95 ) of the activation energy. For the modified sample L/1, the same three stages are well seen. The difference observed is mostly connected with that the stage of activation energy reduction shifts to lower conversion values $(0.15-0.40)$, and a region of constant values of activation energy appears with a value equal to $16 \mathrm{~kJ} / \mathrm{mol}$. Presumably, the first two stages relate to the processes of volatile matter release and oxidation, and the third stage - to the coke residue oxidation. At the same time, in the range of conversion degree of 0.67 , the difference in the values of activation energy between the modified and reference samples is insignificant, which indirectly indicates that the modifying additive has a smaller effect on the kinetics of coke residue conversion.

Similar dependencies can be highlighted for the samples of the bituminous coal (Fig. 9b), but in the region of higher values of the activation energy, from 40 to $160 \mathrm{~kJ} / \mathrm{mol}$. At the same time, for sample $B / 1$, a decrease in the activation energy values is observed in the entire range of conversion. This suggests that for coals with a higher rank, the introduction of additive contributes to the simultaneous 
Table 4 Characteristics of the lignite and bituminous coal oxidation using copper salt additives calculated from TG data. The flow rate is $60 \mathrm{~mL} /$ min (air); the heating rate is $2.5^{\circ} \mathrm{C} / \mathrm{min}$; the temperature range is $45-600{ }^{\circ} \mathrm{C}$; the sample loading is about $17 \mathrm{mg}$

\begin{tabular}{|c|c|c|c|c|c|c|c|c|}
\hline \multirow[t]{2}{*}{ Parameter } & \multicolumn{4}{|l|}{ L series } & \multicolumn{4}{|l|}{ B series } \\
\hline & $\mathrm{L}$ & $\mathrm{L} / 1$ & $\mathrm{~L} / 2$ & $\mathrm{~L} / 3$ & B & $\mathrm{B} / 1$ & $\mathrm{~B} / 2$ & $\mathrm{~B} / 3$ \\
\hline$T_{\mathrm{i}}\left({ }^{\circ} \mathrm{C}\right)$ & 254.0 & 202.0 & 234.0 & 213.0 & 301.0 & 207.0 & 214.0 & 262.0 \\
\hline$t_{\mathrm{e}}(\min )$ & 83.6 & 62.8 & 75.6 & 67.2 & 102.4 & 64.8 & 67.6 & 86.8 \\
\hline$T_{\mathrm{f}}\left({ }^{\circ} \mathrm{C}\right)$ & 464.0 & 403.0 & 408.0 & 394.0 & 550.0 & 446.0 & 497.0 & 473.0 \\
\hline$t_{\mathrm{f}}(\min )$ & 84.0 & 80.4 & 69.6 & 72.4 & 99.6 & 95.6 & 113.2 & 84.4 \\
\hline$T_{\max 1} / T_{\max 2}^{\mathrm{a}}$ & $360 /-$ & $278 / 347$ & $296 /-$ & $242 / 313$ & $338 / 489$ & $326 / 440$ & $338 / 412$ & $282 / 448$ \\
\hline$w_{\max 1} / w_{\max 2}^{\mathrm{a}}(\mathrm{wt} \% / \min )$ & $1.6 /-$ & $1.2 / 1.2$ & $1.7 /-$ & $1.5 / 1.6$ & $0.8 / 1.2$ & $1.2 / 0.4$ & $0.9 / 1.1$ & $0.7 / 1$ \\
\hline $\mathrm{t}_{\max 1} / \mathrm{t}_{\max 2}^{\mathrm{a}}$ & $42.4 /-$ & $30.4 / 18$ & $24.8 /-$ & $11.6 / 8$ & $14.8 / 33.2$ & $47.6 / 16.0$ & $49.6 / 38.4$ & $8 / 51.2$ \\
\hline
\end{tabular}

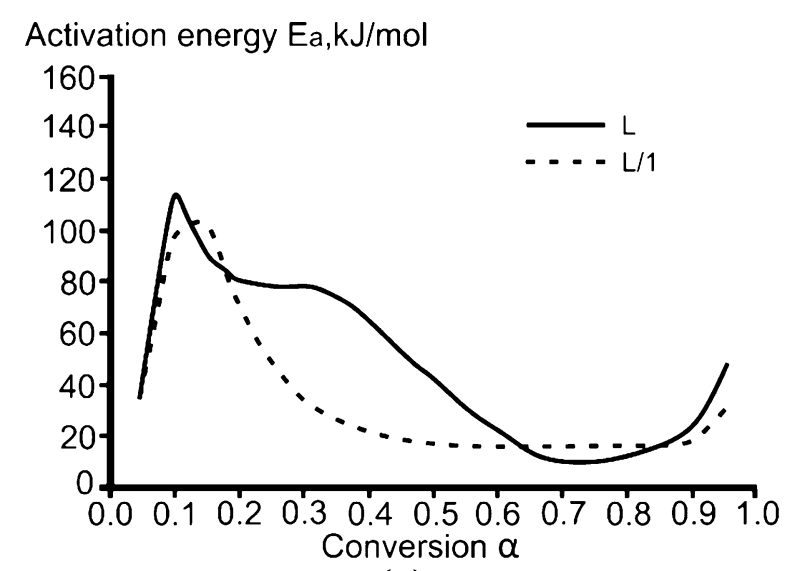

(a)

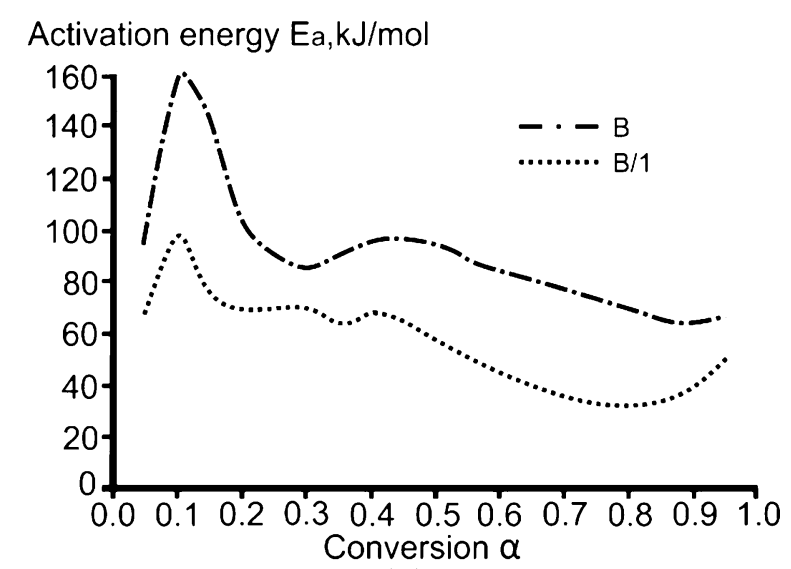

(b)

Fig. 9 Dependence of the activation energy on the conversion of lignite $\mathbf{a}$ and bituminous coal $\mathbf{b}$ samples for the initial and copper nitrate modified samples. The activation energy values were defined at heating rates of $2.5,10,25$, and $40{ }^{\circ} \mathrm{C} / \mathrm{min}$

promotion of both the pyrolysis process and the further conversion of coke residue.

The average decrease in the activation energy $\Delta E_{\mathrm{a}}$ (as a result of the copper nitrate deposition) for lignite samples is $14 \mathrm{~kJ} / \mathrm{mol}$, while for the bituminous coal it is about
$35 \mathrm{~kJ} / \mathrm{mol}$. The maximal difference between the activation energy values for the initial and modified lignite samples was about $48 \mathrm{~kJ} / \mathrm{mol}$ at a conversion degree of 0.35 , for bituminous coal about $60 \mathrm{~kJ} / \mathrm{mol}$ at a conversion degree of 0.1 . The certain difference in the activating effects of the additives on the conversion of lignite and bituminous coal should be noted. In the case of lignite, the minimum and maximum values of the activation energy did not change, and the maximum decrease was observed within the conversion range of $(0.2 / 0.6)$. At the same time, for bituminous coal, there is a relatively even decrease in the activation energy throughout the entire conversion range, and the most significant change of $E_{\mathrm{a}}$ appears within the conversion ranges of $0.05 / 0.3$ to $0.5 / 0.9$.

It is seen for the region of high conversion degrees $(0.90-0.95)$ that a sharp increase in this value is observed for all the samples, which can be explained by the rupture of the most strong chemical bonds between carbon atoms (Zhang et al. 2017).

\section{Conclusion}

In the present work, the promoting effect of different copper salt additives $\left(\mathrm{Cu}\left(\mathrm{NO}_{3}\right)_{2}, \mathrm{Cu}\left(\mathrm{CH}_{3} \mathrm{COO}\right)_{2}, \mathrm{CuSO}_{4}\right)$ on the character of lignite and bituminous coal oxidation was investigated. The results of TGA analysis permit one to establish the following activity rank for the considered additives:

$$
\begin{aligned}
& \mathrm{Cu}\left(\mathrm{NO}_{3}\right)_{2}>\mathrm{Cu}\left(\mathrm{CH}_{3} \mathrm{COO}\right)_{2}>\mathrm{CuSO}_{4} \text { (for lignite) } \\
& \mathrm{Cu}\left(\mathrm{NO}_{3}\right)_{2}>\mathrm{CuSO}_{4} \\
& \quad>\mathrm{Cu}\left(\mathrm{CH}_{3} \mathrm{COO}\right)_{2}(\text { for bituminous coal })
\end{aligned}
$$

The observed effect is thought to be due to the partial or complete decomposition of salts at the very beginning of heating, which is evidenced by the appearance of oxide gas-phase reaction products interacting with coal particles 
during their oxidation. At the same time, the produced nonstoichiometric copper oxide may also have a certain contribution to the catalytic activation of the oxidation process of coal at higher temperatures.

Analysis of the oxidation process parameters has shown that the use of activating additives allows one to reduce the oxidation onset temperature $T_{\mathrm{i}}$ by $20-94{ }^{\circ} \mathrm{C}$ along with shortening the time required for the complete sample oxidation $t_{\mathrm{f}}$. The maximum shortening effect $\left(\Delta t_{\mathrm{f}}=15.2 \mathrm{~min}\right)$ in the duration of the coal combustible mass oxidation was recorded for sample $\mathrm{B} / 3$.

The calculations of the activation energy made for the samples modified with copper nitrate permits one to conclude that the use of copper salts as the promoter additives reduces the kinetic barrier of thermal decomposition and oxidation reactions, which ultimately leads to a significant acceleration of the entire process, thus shifting it into the low-temperature region.

Acknowledgement This work was supported by the Ministry of Science and Higher Education of the Russian Federation (projects No. FSWW-2020-0022 and AAAA-A17-117041710086-6).

\section{Compliance with ethical standards}

Conflict of interest The authors declare that they have no conflict of interest.

Open Access This article is licensed under a Creative Commons Attribution 4.0 International License, which permits use, sharing, adaptation, distribution and reproduction in any medium or format, as long as you give appropriate credit to the original author(s) and the source, provide a link to the Creative Commons licence, and indicate if changes were made. The images or other third party material in this article are included in the article's Creative Commons licence, unless indicated otherwise in a credit line to the material. If material is not included in the article's Creative Commons licence and your intended use is not permitted by statutory regulation or exceeds the permitted use, you will need to obtain permission directly from the copyright holder. To view a copy of this licence, visit http://creativecommons. org/licenses/by/4.0/.

\section{References}

Chen L, Li L, Li G (2008) Synthesis of CuO nanorods and their catalytic activity in the thermal decomposition of ammonium perchlorate. J Alloys Compd 464:532-536. https://doi.org/10. 1016/j.jallcom.2007.10.058

Coats AW, Redfern JP (1964) Kinetic parameters from thermogravimetric date. Nature 201:68-69. https://doi.org/10.1038/ $201068 \mathrm{a} 0$

Gong X, Guo X, Wang Z (2009) Variation of char structure during anthracite pyrolysis catalyzed by $\mathrm{Fe}_{2} \mathrm{O}_{3}$ and its influence on char combustion reactivity. Energy Fuels 23:4547-4552. https://doi. org/10.1021/ef900550w

Gong X, Guo Z, Wang Z (2010a) Reactivity of pulverized coals during combustion catalyzed by $\mathrm{CeO}_{2}$ and $\mathrm{Fe}_{2} \mathrm{O}_{3}$. Combust Flame 157:351-356. https://doi.org/10.1016/J.COMBUST FLAME.2009.06.025
Gong X, Guo Z, Wang Z (2010b) Variation on anthracite combustion efficiency with $\mathrm{CeO}_{2}$ and $\mathrm{Fe}_{2} \mathrm{O}_{3}$ addition by Differential Thermal Analysis (DTA). Energy 35:506-511. https://doi.org/ 10.1016/j.energy.2009.10.017

Guo Q, Liu Y, Jia W, Yang M, Hu X, Ryu HJ (2014) Performance of Ca-based oxygen carriers decorated by $\mathrm{K}_{2} \mathrm{CO}_{3}$ or $\mathrm{Fe}_{2} \mathrm{O}_{3}$ for coal chemical looping combustion. Energy Fuels 28:7053-7060. https://doi.org/10.1021/ef5013006

Huang CJ, Wang SJ, Wu F, Zhu P, Zhou ZH, Yi JM (2013) The effect of waste slag of the steel industry on pulverized coal combustion. Energy Sour Part A 35:1891-1897. https://doi.org/10.1080/ 15567036.2012.667508

International Energy Agency. Coal information. http://www.iea.org/ statistics/?country=WORLD\&year=2016\&category=Electrici ty\&indicator $=$ ElecGenByFuel \&mode $=$ chart $\&$ dataTable $=E L E C$ TRICITYANDHEAT. Accessed 17 May 2019

Ismagilov ZR, Kerzhentsev MA (1999) Fluidized bed catalytic combustion. Catal Today 47:339-346. https://doi.org/10.1016/ S0920-5861(98)00315-0

Jenkins RG, Morgan ME (1986) Pyrolysis of a lignite in an entrained flow reactor: 3 . Pyrolysis in reactive atmospheres of air, carbon dioxide and wet nitrogen. Fuel 65:769-771. https://doi.org/10. 1016/0016-2361(86)90066-9

Kok MV (2002) An investigation into the thermal behavior of coals. Energ Source 24:899-906. https://doi.org/10.1080/ 00908310290086888

Larionov KB, Gromov AA (2019) Non-isothermal oxidation of coal with $\mathrm{Ce}\left(\mathrm{NO}_{3}\right)_{3}$ and $\mathrm{Cu}\left(\mathrm{NO}_{3}\right)_{2}$ additives. Int $\mathrm{J}$ Coal Sci Technol 6(1):37-50. https://doi.org/10.1007/s40789-018-0229-y

Larionov KB, Mishakov IV, Vedyagin AA, Gubin VE (2019) Effect of an initiating additive of $\mathrm{CuSO}_{4}$ on changes in the characteristics of brown coal oxidation and pyrolysis. Solid Fuel Chemistry 53(2):120-127. https://doi.org/10.3103/ S036152191901004X

Lin Z, Han D, Li S (2012) Study on thermal decomposition of copper (II) acetate monohydrate in air. $\mathrm{J}$ Therm Anal Calorim 107:471-475. https://doi.org/10.1007/s10973-011-1454-4

Liu J, Luo L, Ma J, Zhang H, Jiang X (2016) Chemical properties of superfine pulverized coal particles. 3. Nuclear magnetic resonance analysis of carbon structural features. Energy Fuels 30:6321-6329. https://doi.org/10.1021/acs.energyfuels.6b01029

Li XG, Ma BG, Xu L, Luo ZT, Wang K (2007) Catalytic effect of metallic oxides on combustion behavior of high ash coal. Energy Fuels 21:2669-2672. https://doi.org/10.1021/ef070054v

Morgan ME, Jenkins RG (1986a) Pyrolysis of a lignite in an entrained flow reactor: 1. Effect of cations on total weight loss. Fuel 65:757-763. https://doi.org/10.1016/0016-2361(86)90064-5

Morgan ME, Jenkins RG (1986b) Pyrolysis of a lignite in an entrained flow reactor: 2. Effect of metal cations on decarboxylation and tar yield. Fuel 65:764-768. https://doi.org/10.1016/00162361(86)90065-7

Morozov IV, Znamenkov KO, Korenev YM, Shlyakhtin OA (2003) Thermal decomposition of $\mathrm{Cu}\left(\mathrm{NO}_{3}\right)_{2} \cdot 3 \mathrm{H}_{2} \mathrm{O}$ at reduced pressures. Thermochim Acta 403:173-179. https://doi.org/10.1016/S00406031(03)00057-1

Obaid AY, Alyoubi AO, Samarkandy AA, Al-Thabaiti SA, Al-Juaid SS, El-Bellihi AA, Deifallah El-HM (2000) Kinetics of thermal decomposition of copper (II) acetate monohydrate. J Therm Anal Calorim 61(3):985-994. https://doi.org/10.1023/A: 1010179532267

Parmon VN, Simonov AD, Sadykov VA, Tikhov SF (2015) Catalytic combustion: achievements and problems. Combust Explos Shock Waves 51(2):143-150. https://doi.org/10.1134/ S001050821502001X

Ruiz ML, Lick ID, Ponzi MI, Castellón ER, Jiménez-López A, Ponzi EN (2010) Thermal decomposition of supported lithium nitrate 
catalysts. Thermochim Acta 499(1-2):21-26. https://doi.org/10. 1016/j.tca.2009.10.016

Ryu SK, Lee WK, Park SJ (2004) Thermal decomposition of hydrated copper nitrate $\left[\mathrm{Cu}(\mathrm{NO} 3)_{2} \cdot 3 \mathrm{H}_{2} \mathrm{O}\right]$ on activated carbon fibers. Carbon Sci 5:180-185

Santos JCO, Oliveria AD, Silva CC, Silva JDS, Souza AG, Lima LN (2007) Kinetic and activation thermodynamic parameters on thermal decomposition of synthetic lubricant oils. J Therm Anal Calorim 87:823-829. https://doi.org/10.1007/s10973-006-77740

Senneca O, Scala F, Chirone R, Salatino P (2017) Relevance of structure, fragmentation and reactivity of coal to combustion and oxy-combustion. Fuel 201:65-80. https://doi.org/10.1016/j.fuel. 2016.11.034

Shao W, Wang Z, Zhang X, Wang L, Ma Z, Li Q, Zhang Z (2016) Promotion effects of cesium on perovskite oxides for catalytic soot combustion. Catal Lett 146(8):1397-1407. https://doi.org/ 10.1007/s10562-016-1764-z

Simonov AD, Fedorov IA, Dubinin YV, Yazykov NA, Yakovlev VA, Parmon VN (2013) Catalytic heat-generating units for industrial heating. Catal Indus 5(1):42-49. https://doi.org/10.1134/ S207005041301008X

Slyusarskiy KV, Larionov KB, Osipov VI, Yankovsky SA, Gubin VE, Gromov AA (2017) Non-isothermal kinetic study of bituminous coal and lignite conversion in air and in argon/air mixtures. Fuel 191:383-392. https://doi.org/10.1016/j.fuel.2016.11.087

Sriramoju SK, Rashmi, Suresh A, Dash PS (2019) Generation of low ash fine clean coal powder by autogenous grinding process powder technology. Powder Technol 342:67-72. https://doi.org/ 10.1016/j.powtec.2018.09.079

Tabakaev R, Kanipa I, Astafev A, Dubinin Y, Yazykov N, Zavorin A, Yakovlev V (2019) Thermal enhancement of different types of biomass by low temperature pyrolysis. Fuel 245(5):29-38. https://doi.org/10.1016/j.fuel.2019.02.049

Tokareva IV, Mishakov IV, Vedyagin AA, Korneev DV, Petuhkova ES, Savvinova ME (2014) Modification of carbon fibers forrein forcingpipe polyethylene. Compos Nanostruct 6(3):158-167

Vyazovkin S, Burnham AK, Criado JM, Pérez-Maqueda LA, Popescu C, Sbirrazzuoli N (2011) ICTAC Kinetics Committee recommendations for performing kinetic computations on thermal analysis data. Thermochim Acta 520:1-19. https://doi.org/10. 1016/j.tca.2011.03.034

Wang DM, Xin HH, Qi XY, Dou GL, Qi GS, Ma LY (2016) Reaction pathway of coal oxidation at low temperatures: a model of cyclic chain reactions and kinetic characteristics. Combust Flame 163:447-460. https://doi.org/10.1016/j.combustflame.2015.10. 019

Wang J, Zhang SY, Guo X, Dong AX, Chen C, Xiong SW, Fang YT, Yin WD (2012) Thermal behaviors and kinetics of pingshuo coal/biomass blends during copyrolysis and cocombustion. Energy Fuels 26(12):7120-7126. https://doi.org/10.1021/ ef301473k

Wang Y, Wang J, Chen H, Yao M, Li Y (2015a) Preparation and $\mathrm{NO}_{\mathrm{x}}$-assisted soot oxidation activity of a $\mathrm{CuO}-\mathrm{CeO}_{2}$ mixed oxide catalyst. Chem Eng Sci 135:294-300. https://doi.org/10. 1016/j.ces.2015.03.024

Wang Z, Lu P, Zhang X, Wang L, Li Q, Zhang Z (2015b) $\mathrm{NO}_{\mathrm{x}}$ storage and soot combustion over well-dispersed mesoporous mixed oxides via hydrotalcite-like precursors. RSC Adv 5:52743-52753. https://doi.org/10.1039/C5RA07414B

Wayne HR (2005) Copper Compounds. Ullmann's Encyclopedia of Industrial Chemistry. Wiley, Weinheim, pp 273-298

Wei L, Zhang N, Yang T (2012) Effects of alkaline earth metal on combustion of pulverized coal. Adv Mater Res 516-517:271-275. https://doi.org/10.4028/www.scientific.net/ AMR.516-517.271

Xie JL, He F (1998) Catalytic combustion study of anthracite in cement kiln. J Chin Ceram Soc 26:792-795

Zhang L, Hu S, Chen Q, Xiao L, Shatir A, Syed-Hassan SSA, Jiang L, Wang Y, Su S, Xiang J (2017) Molecular structure characterization of the tetrahydrofuran-microwave-extracted portions from three Chinese low-rank coals. Fuel 189:178-185. https:// doi.org/10.1016/j.fuel.2016.10.082

Zhao GW, Yu WQ, Xiao YH (2011) Study on brown coal pyrolysis and catalytic pyrolysis. Adv Mater Res 236-238:660-663. https://doi.org/10.4028/www.scientific.net/AMR.236-238.660

Zou C, Zhao J, Li X, Shi R (2016) Effects of catalysts on combustion reactivity of anthracite and coal char with low combustibility at low/high heating rate. J Therm Anal Calorim 126:1469-1480. https://doi.org/10.1007/s10973-016-5806-y 